\title{
Non-neoplastic indications and outcomes of the proximal and distal femur megaprosthesis: a critical review
}

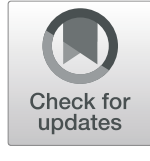

Raju Vaishya, Sunil Singh Thapa and Abhishek Vaish*

\begin{abstract}
Purpose: Megaprosthesis or endoprosthetic replacement of the proximal and distal femur is a well-established modality for treatment of tumors. The indications for megaprosthesis have been expanded to the treatment of some non-neoplastic conditions of the knee and hip, with the severe bone loss associated with failed arthroplasty, communited fractures in the elderly with poor bone quality, and resistant non-union. Th aim of this study is to find out whether megaprosthesis of the knee and hip is successful in the treatment of non-neoplastic condtions. The study comprises a review of the indications, complications, and outcomes of megaprosthesis of the proximal and distal femur in non-neoplastic conditions of the knee and hip joints.
\end{abstract}

Methods: We extensively reviewed the literature on non-neoplastic indications for megaprosthesis of the proximal and distal femur after performing a detailed search of the Pubmed database using the medical subject heading (MeSH) terms 'proximal femur replacement' or 'distal femur replacement' and 'hip or knee megaprosthesis.' The data obtained after the structured search were entered into a Microsoft Excel spreadsheet. The frequency distribution of the demographic data, indications, complications, and outcome was calculated.

Result: We included ten studies (seven proximal femur replacement and three distal femur replacement) of 245 proximal femur and 54 distal femur mega prostheses for treatment of non-neoplastic conditions. Bone loss in failed arthroplasty, either due to periprosthetic fracture or deep infection, was the most common indication for megaprosthesis. Dislocation was the most common complication after proximal femur megaprosthesis, and infection was the leading cause of complications after distal femur megaprosthesis.

Conclusion: Megaprosthesis for treatment of non-neoplastic conditions around the distal and proximal femur is a viable option for limb salvage, with an acceptable long-term outcome. Although the complications and survival rates of megaprosthesis in non-neoplastic conditions are inferior to a primary arthroplasty of the hip and knee but are comparable or better than the mega prosthetic replacement in the neoplastic conditions. Proximal femoral megaprosthesis has higher dislocation rates and requirement for revision compared to distal femoral megaprosthesis. However, the proximal femoral megaprosthesis has lower rates of infection, periprosthetic fractures, and soft tissue complications, as compared to distal femoral megaprosthetic replacement. Both associated with aseptic loosening but not statistically significant.

Keywords: Megaprosthesis, Total knee arthroplasty, Total Hip Arthroplasty, Bone tumors, Neoplasia, Fractures

\footnotetext{
* Correspondence: drabhishekvaish@gmail.com

Department of Orthopaedics and Joint Replacement Surgery, Indraprastha

Apollo Hospital, SaritaVihar, New Delhi 110076, India
}

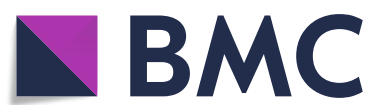

Part of Springer Nature (c) The Author(s). 2020 Open Access This article is licensed under a Creative Commons Attribution 4.0 International License, which permits use, sharing, adaptation, distribution and reproduction in any medium or format, as long as you give appropriate credit to the original author(s) and the source, provide a link to the Creative Commons licence, and indicate if changes were made. The images or other third party material in this article are included in the article's Creative Commons licence, unless indicated otherwise in a credit line to the material. If material is not included in the article's Creative Commons licence and your intended use is not permitted by statutory regulation or exceeds the permitted use, you will need to obtain permission directly from the copyright holder. To view a copy of this licence, visit http://creativecommons.org/licenses/by/4.0/ The Creative Commons Public Domain Dedication waiver (http://creativecommons.org/publicdomain/zero/1.0/) applies to the data made available in this article, unless otherwise stated in a credit line to the data. 


\section{Summary}

Megaprosthesis or endoprosthetic replacement of the proximal and distal femur is a well-established modality for the treatment of tumors. The indications for megaprosthesis have been expanded to the treatment of some non-neoplastic conditions of the knee and hip, with the severe bone loss associated with failed arthroplasty, communited fractures in the elderly with poor bone quality, and resistant non-union. Very few systematic reviews are available on proximal or distal femoral replacement for treatment of non-neoplastic conditions. This study reviews the indications, complications, and the outcomes of the megaprosthesis of the proximal and distal femur, in non-neoplastic conditions of the knee and hip joints. We included ten studies (seven on proximal femur replacement and three on distal femur replacement) of 245 proximal femur and 54 distal femur megaprostheses for treatment of nonneoplastic conditions. Bone loss in failed arthroplasty, either due to periprosthetic fracture or deep infection was the most common indication for megaprosthesis. Dislocation was the most common complication after proximal femur megaprosthesis and infection was the leading cause of complications after distal femur megaprosthesis. Proximal and distal femur megaprosthesis can be used as a salvage procedure in non-neoplastic conditions, with massive bone loss. Megaprosthesis for treatment of non-neoplastic conditions around the distal and proximal femur is a viable option for limb salvage, with an acceptable long-term outcome. Although the complications and survival rates after megaprosthesis in non-neoplastic conditions are inferior to primary arthroplasty of the hip and knee but are comparable or better than the mega prosthetic replacement in the neoplastic conditions. Proximal femoral megaprosthesis has higher dislocation rates and requirement for revision compared to distal femoral megaprosthesis. However, proximal femoral megaprosthesis has lower rates of infection, periprosthetic fractures, and soft tissue complications, as compared to distal femoral megaprosthetic replacement. Both of these procedures have a statistically insignificant difference in the aseptic loosening of the prosthesis. Dislocations in proximal femur megaprosthesis and infection in distal femur megaprosthesis are the major significant complications.

\section{Introduction}

Megaprosthesis or endoprosthetic replacement has been the standard of care for orthopaedic oncology for many decades [11]. Severe bone stock deficiency in the proximal or distal femur, as seen in septic or aseptic failed hip or knee arthroplasty and osteoporotic fracture in the elderly with severe comminution or failed fracture fixation, precludes the use of conventional prostheses. The treatment options available in such a situation are structural allograft-prosthesis composite, impaction allografting, long cemented or press-fit revision stem resection arthroplasty and megaprosthesis $[1,21]$. There are many limitations associated with the use of allograft for reconstruction in bone loss, thus increasing the use of megaprosthesis for tumor surgery $[5,6]$. Encouraging results of the successful outcome of megaprosthesis for tumor salvage in the proximal and distal femur have broadened the indications for megaprosthesis for the treatment of non-neoplastic conditions with extensive bone loss in the proximal or distal femora $[8,19]$.

Very few systematic reviews are available on proximal or distal femoral replacement for treatment of nonneoplastic conditions [20, 24]. Two recent systematic reviews on megaprosthesis for treatment of non-neoplastic conditions of the proximal and distal femur found overall midterm survival rates of $76 \%$ and $83 \%$ for proximal and distal femoral prostheses, respectively $[14,15]$. The main aim of this study is to review the literature and analyze the demography, indications, complications, and outcomes of proximal or distal femur megaprosthesis for the treatment of non-neoplastic conditions. We also attempted to compare the complications and outcomes of proximal and distal femoral megaprosthesis.

\section{Material and methods Literature search}

We searched the Pubmed database for literature on megaprosthesis of the proximal or distal femur for the treatment of non-neoplastic conditions, to access the most relevant studies, on 10 July 2019. The keywords used in the Pubmed search were 'proximal femoral replacement' or 'distal femur replacement' and 'hip or knee megaprosthesis.'

\section{Eligibility criteria}

The inclusion criterion was articles that described the use of a proximal or distal femur megaprosthesis for treatment of non-neoplastic conditions. Case reports and the reports on the use of megaprosthesis for treatment of tumors were excluded.

\section{Data collection}

The authors screened the abstracts of possibly relevant articles and studied the full text of those articles meeting the inclusion criterion. Articles on proximal femur and distal femur megaprosthesis were reviewed separately. Data were extracted on type of study, number of patients, age, indications, complications, and follow up. Complications were classified according to the system reported by Henderson et al. [12], as previously modified for use in non-neoplastic conditions [14], as soft-tissue complications (type 1), aseptic loosening (type 2), structural complications or periprosthetic fracture (type 3), and peri-megaprosthetic infections (type 4). Data on revision and survival rates were also recorded when available. The data were then registered in a Microsoft Excel sheet, and the frequency distribution and the mean were calculated. 


\section{Results}

\section{Search results}

A total of 2682 articles was identified after the initial Pubmed search. 2173 articles revealed full available texts which were further screened. All the relevant articles on non-neoplastic conditions were then screened. All the articles with full text and those meeting the inclusion criterion were selected for this study. A total of ten studies (seven on proximal femur megaprosthesis and three on distal femur megaprosthesis) fulfilled the eligibility criterion. The search strategy is illustrated in Fig. 1.

Out of ten studies, four on proximal femur megaprosthesis and two on distal femur megaprosthesis were prospective studies. We analyzed data on 245 proximal femur megaprostheses (in 243 patients) and 54 distal femur megaprostheses (in 54 patients). These studies had a sample size ranging from 8 to 79 (Tables 1 and 3).

\section{Proximal femur megaprosthesis $(n=245)$}

The mean age of the patients was 68.7 years, and the mean follow-up duration was 44.64 months (Table 1).

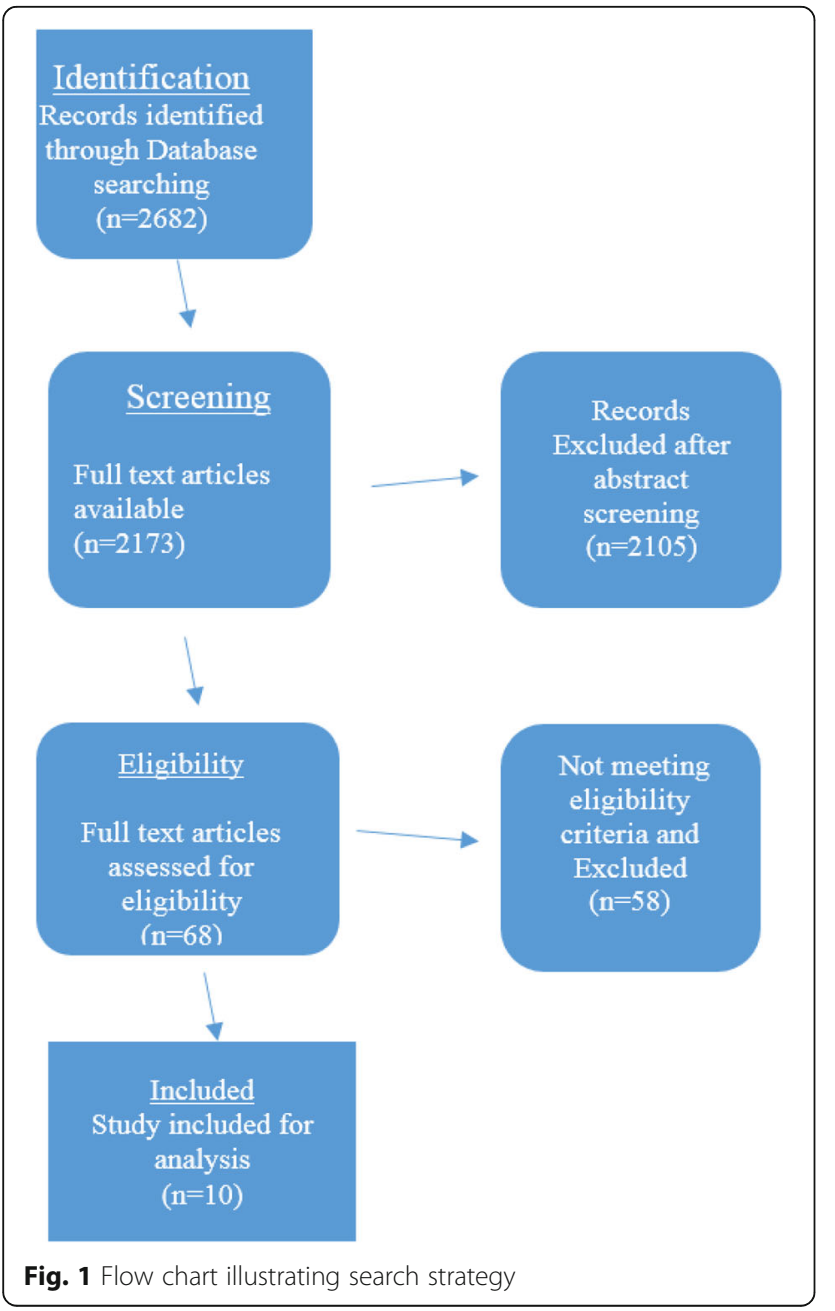

The indications for surgery were periprosthetic infection (28.9\%), periprosthetic fracture $(28.1 \%)$, and massive bone loss due to arthroplasty and complex fractures or failed internal fixation (22.8\%) (Table 2). Dislocation of the prosthesis was the most common complication $(14.6 \%, n=32)$, followed by periprosthetic fracture and aseptic loosening in $7.5 \%$ and $6.9 \%$ of cases, respectively (Table 2). The Harris hip score improved from a preoperative mean of 38.9 to a mean of 72.6 at the last follow up. Out of seven study reports, only four [3, 20, 25, 26] discussed revision and implant survival. A revision was required in 32 cases,and the mean implant survival was $80 \%$ at 5 years (Table 2).

\section{Distal femur megaprosthesis $(n=54)$}

The mean age of the patients was 75.49 years, and the mean follow-up duration was 43.05 months (Table 3). The most common indication for distal femur megaprosthesis was substantial bone loss after failed knee arthroplasty in $55.5 \%$ of cases (Tables 2 and 4). Periprosthetic infection was the most common complication (18.5\% cases) (Tables 2 and 4 ).

The Knee Society Score improved from a preoperative median of 20 to a postoperative median of 80 [27]. Out of three studies, only Vertesich et al. [27] mentioned revision and implant survival in their study. Revision was required in three cases, and the implant survival was $74.8 \%$ at 1 year and $40.9 \%$ at 10 years (Table 4 ).

\section{Comparison of complications of the proximal femur and distal femur megaprosthesis}

Proximal femoral megaprosthesis has higher dislocation rates and requirement for revision compared to distal femoral megaprosthesis. However, proximal femoral megaprosthesis is associated with lower rates of infection, periprosthetic fractures, and soft tissue complications, as compared to distal femoral megaprosthetic replacement. Both of these procedures have a statistically insignificant difference in the aseptic loosening of the prosthesis (Fig. 2).

\section{Discussion}

Megaprosthesis of the proximal or distal femur is a viable option for limb reconstruction in non-neoplastic conditions like failed hip or knee arthroplasty, periprosthetic fractures, osteoporotic fracture with severe comminution, or resistant non-union in elderly patients [2, 29]. Megaprosthesis in such cases should be considered as a limb salvage option in carefully selected patients when other surgical options are not feasible [14]. In this review, we analyzed the complications and outcome of proximal and distal femur megaprosthesis.

Failed hip arthroplasty with extensive bone loss (due to infection, fracture, or aseptic loosening) was the most common (83.6\%) non-neoplastic indication for proximal 
Table 1 Study design, number of prostheses, mean age, and follow up of proximal femur megaprosthesis

\begin{tabular}{lllll}
\hline Authors & Study design & Number of cases of megaprosthesis & Age, years & Follow up, months \\
\hline Malkani AL et al.; 1995 [20] & Retrospective & 32 (33 prostheses) & 60.6 & 133.2 \\
Parvizi J et al.; 2007 [3] & Retrospective & 48 & 73.8 & 36.5 \\
Shih ST et al.; 2007 [22] & Prospective & 12 & $59(25-75)$ & $68.4(3.3-9$ years) \\
Dean BJ et al.; 2012 [23] & Prospective & 8 & $67.5(50-79)$ & $16.5(6-36)$ \\
McLean AL et al.; 2012 [24] & Prospective & 20 & $72(36-91)$ & $48(12-116)$ \\
Grammatopoulos G et al.; 2016 [25] & Retrospective & 79 (80 prostheses) & $69(28-93)$ & $60(0-11.5$ years) \\
Viste A et al.; 2017 [26] & Prospective & 44 & $79(53-97)$ & $72(2-12$ years) \\
Total & & 243 (245 prostheses) & 68.7 years & 44.64 \\
\hline
\end{tabular}

Table 2 Indications, complications, Harris hip score, and revision and implant survival of proximal femur megaprosthesis

\begin{tabular}{|c|c|c|c|c|c|}
\hline Authors & Indications & Complications & $\begin{array}{l}\text { Harris Hip } \\
\text { Score }\end{array}$ & $\begin{array}{l}\text { Revision } \\
\text { surgery }\end{array}$ & Implant survival \\
\hline $\begin{array}{l}\text { Malkani AL et al.; } \\
1995 \text { [20] }\end{array}$ & Massive femoral bone loss $(n=33)$ & $\begin{array}{l}\text { Dislocation }(n=11) \text { Aseptic loosening } \\
(n=11)\end{array}$ & $\begin{array}{l}\text { Preop } 46 \\
\text { (31-83) } \\
\text { Postop } 80 \\
(50-91)\end{array}$ & $\begin{array}{l}\text { Revision } \\
(n=11)\end{array}$ & $64 \%$ at 12 years \\
\hline $\begin{array}{l}\text { Parvizi J et al.; } \\
2007 \text { [3] }\end{array}$ & $\begin{array}{l}\text { Periprosthetic fracture }(n=20) \\
\text { Infection }(n=13) \\
\text { Failed arthroplasty }(n=13) \\
\text { Non-union of fracture }(n=1) \\
\text { Radiation AVN }(n=1)\end{array}$ & $\begin{array}{l}\text { Dislocation }(n=8) \\
\text { Aseptic loosening }(n=4) \\
\text { Periprosthetic infection }(n=1)\end{array}$ & $\begin{array}{l}\text { Preop } 37.1 \\
(15-61) \\
\text { Postop } \\
64.9(13- \\
91)\end{array}$ & $\begin{array}{l}\text { Revision } \\
(n=10)\end{array}$ & $\begin{array}{l}87 \% \text { at } 1 \text { year } \\
\text { and } \\
73 \% \text { at } 5 \text { years }\end{array}$ \\
\hline $\begin{array}{l}\text { Shih ST et al.; } \\
2007 \text { [22] }\end{array}$ & $\begin{array}{l}\text { Periprosthetic fracture }(n=2) \\
\text { Periprosthetic infection }(n=6) \\
\text { Aseptic loosening }(n=3) \\
\text { Allograft fracture }(n=1)\end{array}$ & $\begin{array}{l}\text { Dislocation }(n=5) \\
\text { Aseptic loosening }(n=1) \\
\text { Displaced fracture }(n=3) \\
\text { Deep infection }(n=4) \\
\text { Leg shortening }(n=2) \\
\text { Ectopic ossification }(n=1)\end{array}$ & $\begin{array}{l}\text { Preop } 30 \\
(16-42) \\
\text { Postop } 83 \\
(68-92)\end{array}$ & $\begin{array}{l}\text { Not } \\
\text { mentioned }\end{array}$ & Not mentioned \\
\hline $\begin{array}{l}\text { Dean BJ et al.; } \\
2012 \text { [23] }\end{array}$ & $\begin{array}{l}\text { Failed internal fixation for proximal femur } \\
\text { fracture }(n=8)\end{array}$ & No & $\begin{array}{l}71.4(64- \\
85)\end{array}$ & $\begin{array}{l}\text { Not } \\
\text { mentioned }\end{array}$ & Not mentioned \\
\hline $\begin{array}{l}\text { McLean AL et al.; } \\
2012 \text { [24] }\end{array}$ & Periprosthetic femoral fracture $(n=20)$ & $\begin{array}{l}\text { Dislocation }(n=3) \\
\text { Periprosthetic fracture }(n=1)\end{array}$ & $\begin{array}{l}\text { Not } \\
\text { mentioned }\end{array}$ & $\begin{array}{l}\text { Not } \\
\text { mentioned }\end{array}$ & Not mentioned \\
\hline $\begin{array}{l}\text { Grammatopoulos } \\
\text { G et al.; } 2016 \text { [25] }\end{array}$ & $\begin{array}{l}\text { Periprosthetic joint infection }(n=40) \\
\text { Periprosthetic fracture }(n=12) \\
\text { Failed osteosynthesis of a fracture }(n=16) \\
\text { Miscellaneous }(n=9)\end{array}$ & $\begin{array}{l}\text { Infection }(n=9) \\
\text { Dislocation }(n=3) \text {. }\end{array}$ & NA & $\begin{array}{l}\text { revision } \\
(n=9)\end{array}$ & $\begin{array}{l}87 \%(95 \% \mathrm{Cl} \\
76-98 \%) \text { at } 5 \\
\text { years }\end{array}$ \\
\hline $\begin{array}{l}\text { Viste A et al.; } \\
2017 \text { [26] }\end{array}$ & $\begin{array}{l}\text { Aseptic loosening }(n=16) \\
\text { Periprosthetic fracture }(n=15) \\
\text { Prosthetic joint infection }(n=12) \\
\text { Instability }(n=1)\end{array}$ & $\begin{array}{l}\text { Dislocation }(n=6) \\
\text { Aseptic loosening }(n=1) \\
\text { Periprosthetic fracture }(n=4) \\
\text { Infection }(n=1)\end{array}$ & $\begin{array}{l}\text { Preop 42.8 } \\
(25.9-82.9) \\
\text { Postop } \\
68.5(21.0- \\
87.7)\end{array}$ & $\begin{array}{l}\text { Revision } \\
(n=2)\end{array}$ & $\begin{array}{l}86 \% \text { at } 5 \text { years } \\
\text { and } \\
66 \% \text { at } 10 \text { years }\end{array}$ \\
\hline Total & $\begin{array}{l}\text { 1. Periprosthetic fracture }(n=69,28.1 \%) \\
\text { 2. Periprosthetic infection }(n=71,28.9 \%) \\
\text { 3. Massive femoral bone loss in } \\
\text { arthroplasty ( } n=33,13.4 \%) \\
\text { 4. Failed internal fixation for proximal } \\
\text { femur fracture and complex fracture ( } n= \\
\text { 24, } 9.7 \%) \\
\text { 5. Aseptic loosening }(n=19,7.7 \%) \\
\text { 6. Miscellaneous }(n=16,6.5 \%) \\
\text { 7. Failed arthroplasty }(n=13,5.3 \%)\end{array}$ & $\begin{array}{l}\text { 1. Dislocation ( } n=36,14.6 \%) \text {. } \\
\text { 2. Aspetic loosening }(n=19,7.5 \%) \\
\text { 3. Periposthetic fracture }(n=8,3.2 \%) \\
\text { 4. Periposthetic infection }(n=17,6.9 \%) \text {. } \\
{ }^{*} \text { miscallenous soft tissue complications } \\
(n=3)\end{array}$ & $\begin{array}{l}\text { Mean } \\
\text { preop }= \\
38.9 \\
\text { and } \\
\text { mean post } \\
o p=72.6\end{array}$ & $\begin{array}{l}\text { Revision } \\
(n=32 \\
13.06 \%)\end{array}$ & $\begin{array}{l}\text { Mean }-80 \% \text { at } \\
5 \text { years }\end{array}$ \\
\hline
\end{tabular}


Table 3 Study design, number of prostheses, mean age, and follow up of distal femur megaproshthesis

\begin{tabular}{lllll}
\hline Authors & Study design & Number of patients & Age (years) & Follow up (months) \\
\hline Vaishya R et al.; 2011 [12] & Prospective & 10 & $74.38( \pm 10.1)$ & 48 \\
Fakler JK et al.; 2013 [27] & Prospective & 14 & 77 & 27 \\
Vertesich K et al.; 2019 [28] & Retrospective & 30 & 75.1 & $54.15(1-240)$ \\
Total & & 54 & 75.49 & 43.05 \\
\hline
\end{tabular}

femur megaprosthesis (Table 2). Failed total knee arthroplasty $(55.5 \%)$ was the most common non-neoplastic indication for distal femur megaprosthesis (Table 4).

Dislocation of the hip prosthesis is the most common complication observed in this review, seen in $14.6 \%$ of proximal femur megaprostheses (but in none of the distal femur megaprostheses: Table 4). Our results are in agreement with the systematic review by Korim et al. [14], reporting a $15.7 \%$ rate of hip dislocation at a mean follow up of 45 months. The cause of instability is multifactorial, including inability to achieve a secure repair of the residual soft tissues around the metal prosthesis [9] and compromised abductors around the hip due to multiple previous reconstructive procedures. The monobloc implants used previously were less versatile and often led to dislocation, but with the new generation of megaprosthesis providing better provision for more secure soft tissue reattachment and the ability to reapproximate the retained proximal host bone to the prosthesis, the rate of dislocation has decreased [21].

Periprosthetic infection was seen in $6.9 \%$ of proximal femur megaprostheses (hip) and in 18.5\% of distal femur megaprostheses (knee), thus agreeing with previous findings of a mean rate of $7.6 \%$ for proximal femoral prostheses $[13,14]$ and $15 \%$ for distal femoral prostheses [15]. A recent systematic review has reported a mean

Table 4 Indications, complications, Knee Society Score, and revision and implant survival of distal femur megaprosthesis

\begin{tabular}{|c|c|c|c|c|c|}
\hline Authors & Indications & Complications & Knee Society Score (KSS) & Outcomes & Implant survival \\
\hline $\begin{array}{l}\text { Vaishya R } \\
\text { et al.; } \\
2011 \text { [19] }\end{array}$ & $\begin{array}{l}\text { Resistant non-union } \\
\text { supracondylar frac- } \\
\text { ture }(n=10)\end{array}$ & $\begin{array}{l}\text { Wound } \\
\text { necrosis }(n= \\
\text { 2) } \\
\text { Periprosthetic } \\
\text { fracture }(n=1)\end{array}$ & Not mentioned & $\begin{array}{l}\text { Not } \\
\text { mentioned }\end{array}$ & Not mentioned \\
\hline $\begin{array}{l}\text { Fakler JK } \\
\text { et al.; } \\
2013 \text { [27] }\end{array}$ & $\begin{array}{l}\text { Periprosthetic } \\
\text { fracture }(n=6) \\
\text { Complex fractures } \\
\text { and extensive bone } \\
\text { defects }(n=8)\end{array}$ & $\begin{array}{l}\text { Patellar } \\
\text { tendon } \\
\text { rupture }(n=1) \\
\text { Early aseptic } \\
\text { loosening } \\
(n=1) \\
\text { Periprosthetic } \\
\text { frature }(n=4) \\
\text { Infection }(n= \\
2)\end{array}$ & $\begin{array}{l}\text { KSS improved significantly from } 20.0 \text { (IQB 7.5- } \\
\text { 30.0) points preoperatively to } 80.0 \text { (IQB } 62.3- \\
\text { 89.0) }\end{array}$ & $\begin{array}{l}\text { Not } \\
\text { mentioned }\end{array}$ & Not mentioned \\
\hline $\begin{array}{l}\text { Vertesich } \\
\text { Ket al; } \\
2019 \text { [28] }\end{array}$ & $\begin{array}{l}\text { Substantial bone } \\
\text { loss following TKA } \\
(n=30)\end{array}$ & $\begin{array}{l}\text { Soft-tissue } \\
\text { complications } \\
(n=3) \\
\text { Aseptic } \\
\text { loosening } \\
(n=4) \\
\text { Periprosthetic } \\
\text { fracture }(n=1) \\
\text { Infection }(n= \\
\text { 8) }\end{array}$ & $\begin{array}{l}\text { DFR achieved } 69.3 \% \text { of KSS pain score, } 23.1 \% \\
\text { KSS function score and } 76.2 \% \text { of ROM } \\
\text { compared to patients with primary TKA }\end{array}$ & $\begin{array}{l}\text { Revision } \\
\text { surgery }(n=3) \\
\text { Transfemoral } \\
\text { amputation } \\
(n=4) \\
\text { Distal femur } \\
\text { reconstruction } \\
(n=1)\end{array}$ & $\begin{array}{l}\text { Revision-free survival was } 74.8 \% \\
\text { at } 1 \text { year, } 62.5 \% \text { at } 3 \text { years and } \\
40.9 \% \text { at } 10 \text { years postop }\end{array}$ \\
\hline Total & $\begin{array}{l}\text { Substantial bone } \\
\text { loss after failed TKA } \\
(n=30) \\
\text { Resistant nonunion } \\
\text { supracondylar } \\
\text { fracture }(n=10) \\
\text { Traumatic fracture } \\
\text { with severe } \\
\text { comminution }(n=8) \\
\text { Periprosthetic } \\
\text { fracture }(n=6)\end{array}$ & $\begin{array}{l}\text { Soft tissue } \\
\text { complications } \\
(n=6) \\
\text { Aseptic } \\
\text { loosening } \\
(n=5) \\
\text { Periprosthetic } \\
\text { fracture }(n=6) \\
\text { Periposthetic } \\
\text { infection ( } n= \\
\text { 10) }\end{array}$ & & $\begin{array}{l}\text { Revision } \\
\text { surgery }(n=3, \\
5.5 \%) \\
\text { Transfemoral } \\
\text { amputation } \\
(n=4) \\
\text { Distal femur } \\
\text { reconstruction } \\
(n=1)\end{array}$ & \\
\hline
\end{tabular}




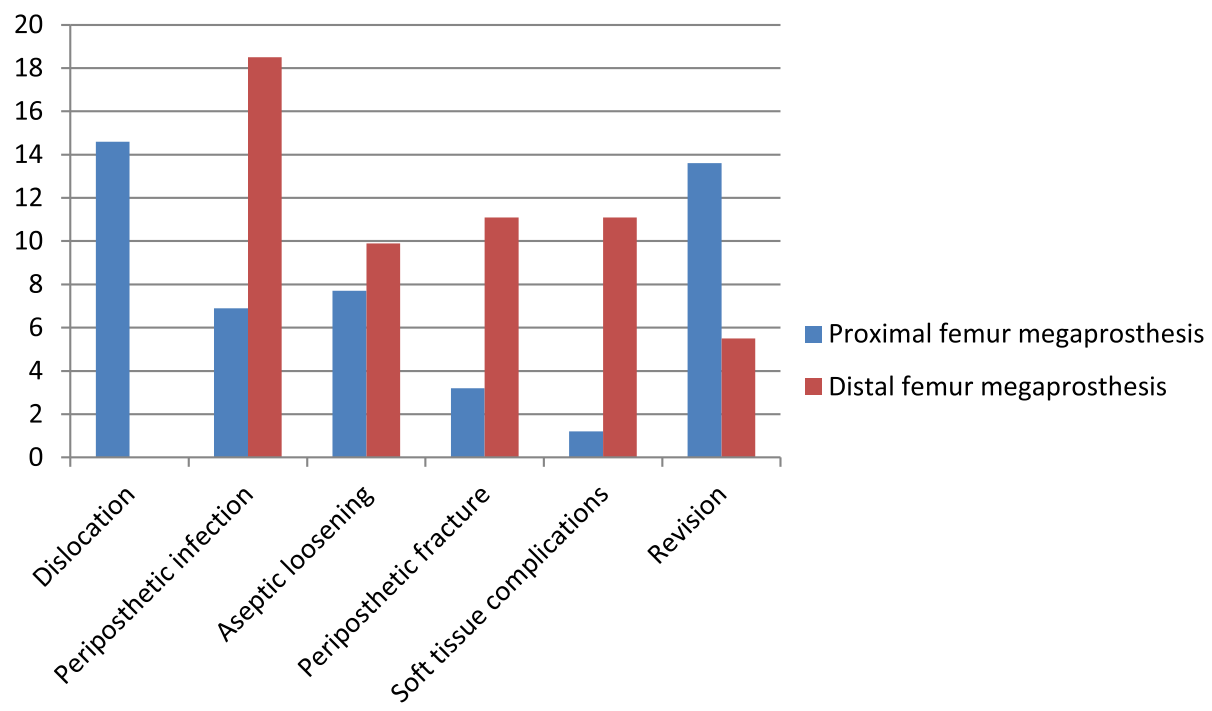

Fig. 2 Comparison of complications of proximal versus distal femur megaprosthesis (expressed in percentage)

rate of peri-megaprosthetic infection of $10 \%$, following tumor resection [22]. The overall infection rate in hip and knee arthroplasty is as low as $1 \%[16,17]$. Periprosthetic infection is common and remains the most challenging complication after megaprosthesis because of poorquality soft tissue due to multiple previous surgeries, poor overall health status, and long operating times [16, 18, 22]. These factors result in a poor functional outcome and failed limb salvage.

Aseptic loosening was seen in $7.7 \%$ and $9.9 \%$ of proximal and distal femur megaprosthesis, respectively. Aseptic loosening of megaprosthesis in the treatment of nonneoplastic diseases has been previously detected with rates ranging from $0 \%$ to $9.5 \%$ [25, 29], and these reports are consistent with aseptic loosening after tumor prosthesis [4]. Periprosthetic fracture was seen in $3.2 \%$ and $11.1 \%$ of cases of proximal and distal femur megaprosthesis, respectively. The mean age of the distal femur cohort was 75.49 years compared to 68.7 years in the proximal femur group; poorer bone quality may be the reason for a higher rate of periprosthetic fracture in this group [26].

Soft tissue complications were seen in $1.2 \%$ and $11.1 \%$ of cases of proximal and distal femur megaprosthesis, respectively (Table 4). In a retrospective review of 2174 patients, Henderson et al. [12] detected an overall rate of soft-tissue complications (i.e., including dislocation) of $5.2 \%$ with primary proximal femoral prosthesis. We found that revision was required in $13.06 \%$ and $5.5 \%$ cases of proximal and distal femur megaprosthesis, respectively. In a systemic review by Korim [9], reoperation rates ranged from $13.3 \%$ to $40 \%$ in proximal femur megaprosthesis.

We found significant improvement in the Harris hip score after proximal femur megaprosthesis and significant improvement in the Knee Society Score after distal femur megaprosthesis. We found that the mean 5-year survival of proximal femur megaprosthesis was $80 \%$, which is comparable $(78-90 \%)$ to that reported for neoplastic indications $[7,8,19]$.

The main limitations of this review were the heterogeneity and the small sample size of the study. Data on the patients who were lost to follow up in most of the studies was lost. Details of the complications and their outcomes could not be assessed thoroughly, as none of the articles except for that of Grammatopoulos et al. [10] reported the complications for each indication and we were able to analyze only three studies on distal femur megaprosthesis.

\section{Conclusion}

Proximal and distal femur megaprosthesis can be used as a salvage procedure for non-neoplastic conditions, with massive bone loss. Proximal femoral megaprosthesis has higher dislocation rates and requirement for revision compared to distal femoral megaprosthesis. However, the proximal femoral megaprosthesis is associated with rates of infection, periprosthetic fractures, and soft tissue complications, as compared to distal femoral megaprosthetic replacement. Both of these procedures have a statistically insignificant difference in the aseptic loosening of the prosthesis. Dislocations in proximal femur megaprosthesis and infection in distal femur megaprosthesis are the major significant complications.

\section{Acknowledgements}

Not applicable.

\section{Authors' contributions}

RV was involved in the conception, providing patient-specific data, and editing the manuscript. SST was involved in writing the manuscript and also 
researching the topic. AV was involved in editing, researching and submitting the manuscript. All authors read and approved the final manuscript.

\section{Funding}

None received.

\section{Availability of data and materials}

Patient-related data were collected from the department with permission of the patient and the treating consultant (author, Dr Raju Vaishya).

\section{Competing interests}

The authors decalre that they have no competing interests.

Received: 28 December 2019 Accepted: 25 February 2020

Published online: 09 April 2020

\section{References}

1. Al-Taki MM, Masri BA, Duncan CP et al (2011) Quality of life following proximal femor replacement using a modular system in revision THA. Clin Orthop Relat Res 469:470-475

2. Calori GM, Colombo M, Malagoli E, Mazzola S, Bucci M, Mazza E (2014) Megaprosthesis in post-traumatic and periprosthetic large bone defects: issues to consider. Injury 45(6):S105-S110

3. Calori GM, Colombo M, Ripamonti C et al (2014) Megaprosthesis in large bone defects: opportunity or chimaera? Injury 45(2):388-393

4. Capanna R, Scoccianti G, Frenos F, Vilardi A, Beltrami G, Campanacci DA (2015) What was the survival of megaprostheses in lower limb reconstructions after tumor resections? Clin Orthop Relat Res 473(3):820-830

5. Chandrasekar CR, Grimer RJ, Carter SR et al (2009) Modular endoprosthetic replacement for tumours of the proximal femur. J Bone Joint Surg (Br) 91-B:108-112

6. Dean BJ, Matthews JJ, Price A, Stubbs D, Whitwell D, Gibbons CM (2012) Modular endoprosthetic replacement for failed internal fixation of the proximal femur following trauma. Int Orthop 36(4):731-734

7. Fakler JK, Hepp P, Marquaß B, Josten C (2013) Is distal femoral replacement an adequate therapeutic option after complex fractures of the distal femur? Zeitschrift fur Orthopadie und Unfallchirurgie 151(2):173-179

8. Gosheger G, Gebert C, Ahrens H et al (2006) Endoprosthetic reconstruction in 250 patients with sarcoma. Clin Orthop Relat Res 450:164-171

9. Gottsauner-Wolf F, Egger EL, Schultz FM et al (1994) Tendons attached to prostheses by tendon-bone block fixation: an experimental study in dogs. J Orthop Res 12:814-821

10. Grammatopoulos G, Alvand A, Martin H, Whitwell D, Taylor A, Gibbons CL (2016) Five-year outcome of proximal femoral endoprosthetic arthroplasty for non-tumour indications. J Bone Joint Surg 98(11):1463-1470

11. Henderson ER, Groundland JS, Pala E, Dennis JA, Wooten R, Cheong D, Windhager R, Kotz RI, Mercuri M, Funovics PT, Hornicek FJ, Temple HT, Ruggieri P, Letson GD (2011) Failure mode classification for tumor endoprostheses: retrospective review of five institutions and a literature review. J Bone Joint Surg Am 93:418-429

12. Henderson ER, Groundland JS, Pala E et al (2011) Failure mode classification for tumor endoprostheses: retrospective review of five institutions and a literature review. J Bone Joint Surg 93(5):418-429

13. Jeys LM, Kulkarni A, Grimer RJ, Carter SR, Tillman RM, Abudu A (2008) Endoprosthetic reconstruction for the treatment of musculoskeletal tumors of the appendicular skeleton and pelvis. J Bone Joint Surg A 90(6):1265-1271

14. Korim MT, Esler CNA, Ashford RU (2014) Systematic review of proximal femoral arthroplasty for non-neoplastic conditions. J Arthroplast 29(11):2117-2121

15. Korim MT, Esler CNA, Reddy VRM, Ashford RU (2013) A systematic review of endoprosthetic replacement for non-tumour indications around the knee joint. Knee 20(6):367-375

16. Lamagni T (2014) Epidemiology and burden of prosthetic joint infections. J Antimicrob Chemother 69(1):i5-i10

17. Malkani AL, Settecerri JJ, Sim FH, Chao EY, Wallrichs SL (1995) Long-term results of proximal femoral replacement for non-neoplastic disorders. J Bone Joint Surg 77(3):351-356

18. McLean AL, Patton JT, Moran M (2012) Femoral replacement for salvage of periprosthetic fracture around a total hip replacement. Injury 43(7):1166-1169

19. Menendez LR, Ahlmann ER, Kermani C, Gotha H (2006) Endoprosthetic reconstruction for neoplasms of the proximal femur. Clin Orthop Relat Res 450:46-51
20. Parvizi J, Sim FH (2004) Proximal femoral replacements with megaprostheses. Clin Orthop Relat Res 420:169-175

21. Parvizi J, Tarity TD, Slenker N et al (2007) Proximal femoral replacement in patients with non-neoplastic conditions. J Bone Joint Surg Am 89:1036

22. Racano A, Pazionis T, Farrokhyar F, Deheshi B, Ghert M (2013) High infection rate outcomes in long-bone tumor surgery with endoprosthetic reconstruction in adults: a systematic review. Clin Orthop Relat Res 471(6): 2017-2027

23. Shih S, Wang J, Hsu C (2007) Proximal femoral megaprosthesis for failed total hip arthroplasty. Chang Keng I Hsueh Chang Gung Med J 30(1):73

24. Sim FH, Chao EY (1981) Hip salvage by proximal femoral replacement. J Bone Joint Surg Am 63:1228-1239

25. Vaishya $R$, Singh AP, Hasija R, Singh AP (2011) Treatment of resistant nonunion of supracondylar fractures femur by megaprosthesis. Knee Surg Sports Traumatol Arthrosc 19(7):1137-1140

26. Vaishya $R$, Singh AP, Vaish A (2013) Periprosthetic subtrochanteric femoral fracture in a megaprosthesis of the knee. Chin J Traumatol 16(5):314-315

27. Vertesich K, Puchner SE, Staats K, Schreiner M, Hipfl C, Kubista B, Holinka J, Windhager R (2019) Distal femoral reconstruction following failed total knee arthroplasty is accompanied with risk for complication and reduced joint function. BMC Musculoskelet Disord 20(1):47

28. Viste A, Perry Kl, Taunton MJ, Hanssen AD, Abdel MP (2017) Proximal femoral replacement in contemporary revision total hip arthroplasty for severe femoral bone loss: a review of outcomes. J Bone Joint Surg 99(3): 325-329

29. Windhager R, Schreiner M, Staats K, Apprich S (2016) Megaprostheses in the treatment of periprosthetic fractures of the knee joint: indication, technique, results and review of literature. Int Orthop 40(5):935-943

\section{Publisher's Note}

Springer Nature remains neutral with regard to jurisdictional claims in published maps and institutional affiliations.

Ready to submit your research? Choose BMC and benefit from:

- fast, convenient online submission

- thorough peer review by experienced researchers in your field

- rapid publication on acceptance

- support for research data, including large and complex data types

- gold Open Access which fosters wider collaboration and increased citations

- maximum visibility for your research: over $100 \mathrm{M}$ website views per year

At $\mathrm{BMC}$, research is always in progress.

Learn more biomedcentral.com/submissions 